\title{
Respiratory Activity and Mitochondrial Oxidative Capacity of Bell Pepper Fruit following Storage under Low-oxygen Atmosphere
}

\author{
Abd-Shukor A. Rahman', Donald J. Huber ${ }^{2}$, and Jeffrey K. Brecht ${ }^{3}$ \\ Horticultural Sciences Department, University of Florida, Gainesville, FL 32611 \\ Additional index words. Capsicum annuum, residual effect, ethylene, ethanol, mitochondrial activity, controlled-atmosphere \\ storage
}

\begin{abstract}
Bell pepper (Capsicum annuum L., var. 'Jupiter') fruit stored in $1.5 \%, 5 \%$, or $10 \% \mathrm{O}_{2}$, or in air at $20 \mathrm{C}$ for 24 hours were compared to determine the residual effect of low-O, storage on respiration after transfer to air. The lowest $\mathrm{O}_{2}$ concentration $(1.5 \%)$ exerted the greatest residual effect on bell pepper fruit $\mathrm{CO}_{2}$ production and $\mathrm{O}_{2}$, uptake. No ethanol was detected in the headspace gas of fruit stored in $1.5 \% \mathrm{O}_{2}$. Carbon dioxide production continued to be suppressed for $\approx 24$ hours after transfer from $1.5 \% \mathrm{O}_{2}$ to air. Exposure to $5 \% \mathrm{O}_{2}$, for 24 hours resulted in less suppression of $\mathrm{CO}$, production and $\mathrm{O}_{2}$ uptake upon transfer to air, while $10 \% \mathrm{O}_{2}$ exerted no residual effect. Extending the storage period in $1.5 \% \mathrm{O}_{2}$ to 72 hours extended the residual effect from 24 to 48 hours. Ethylene production was not affected by storage in $1.5 \%$ or $4 \% \mathrm{O}_{2}$ for 24 or 72 hours. The residual effect exhibited in whole fruit was not apparent in mitochondria isolated from bell pepper stored in $1.5 \%$ or $4 \% \mathrm{O}_{2}$.
\end{abstract}

The benefits of controlled-atmosphere (CA) storage of fresh fruits and vegetables include extended storage life and maintenance of quality. Reduced $\mathrm{O}_{2}$ and elevated $\mathrm{CO}_{2}$ in $\mathrm{CA}$ storage can reduce respiration and ethylene production rates, reduce tissue sensitivity to ethylene, delay ripening and softening, and slow down biochemical changes associated with ripening (Kader, 1986).

Concentrations of $\mathrm{O}_{2}$ and $\mathrm{CO}_{2}$, duration of exposure, and storage temperature are some important criteria for successful CA storage of fresh fruits and vegetables. Tolerance to low-O, levels varies with commodity. Kader (1986) indicated that, for most commodities, a minimum of $1 \%$ to $3 \% \mathrm{O}_{2}$ in the storage environment is required to avoid a shift to anaerobic metabolism. Oxygen concentrations as low as $0.2 \%$ within the plant cell may result in anaerobic respiration. Anaerobiosis normally results in the accumulation of ethanol and acetaldehyde (Patterson and Nichols, 1988), and increased activity of pyruvic decarboxylase (EC 4.1.1.1) and alcohol dehydrogenase (EC 1.1.1.1) (Davis et al., 1973).

Changes in physiological properties and quality attributes following short-term exposure to low $\mathrm{O}_{2}$ have been elucidated for various commodities, including tree fruits (Ke and Kader, 1990; Ke et al., 1991) and strawberry (Fragaria $\times$ ananassa Duch.) fruits (Aharoni et al., 1979). In some commodities, the respiration and ethylene production rates continue to be suppressed even after transfer from a low- $\mathrm{O}_{2}$ environment to air. Li and Kader (1989) have termed this phenomenon the "residual effect" of low- $\mathrm{O}_{2}$ storage. These authors demonstrated that 'Selva' strawberry fruit stored in $0.5 \%$ to $2.0 \% \mathrm{O}_{2}$ at $2 \mathrm{C}$ for 7 days exhibited reduced respiration and ethylene production rates and maintained flesh firmness and color after removal to air. The residual effect was more pronounced following storage at lower $\mathrm{O}_{2}$ concentrations.

Mitochondria are the cellular sites of oxidative phosphoryla-

Received for publication 8 Apr. 1992. Accepted for publication 31 Oct. 1992. Journal article no. R-02683 of the Florida Agricultural Experimental Station. The cost of publishing this paper was defrayed in part by the payment of page charges. Under postal regulations, this paper therefore must be hereby marked advertisement solely to indicate this fact.

'Research Scientist at the Malaysian Agricultural Research and Development Institute (MARDI).

${ }^{2}$ Professor. To whom reprint requests should be addressed.

${ }^{3}$ Associate Professor. tion, where respiratory enzymes are located. Low $\mathrm{O}_{2}$ and high $\mathrm{CO}_{2}$ may influence the activity of these enzymes, depending on the concentration and duration of exposure. Burton (1978) and Solomos ( 1982) have pointed out, however, that the decrease in respiration rate in response to low $\mathrm{O}_{2}$ levels may not be due to a reduction in the activity of cytochrome oxidase (EC 1.9.3.1), a high-affinity, low- $\mathrm{Km}$ oxidase, but rather to the diminished activities of lowaffinity oxidases, such as polyphenol oxidase (EC 1.14.18. I), lipoxygenase (EC 1.13.11.12), and ascorbic acid oxidase (EC 1.10.3.3).

The primary objective of this study was to determine whether low $\mathrm{O}_{2}$ exerts residual effects on respiration of bell pepper fruit. This included an evaluation of whether mitochondrial oxidative capacity was reduced after storage in low $\mathrm{pO}_{2}$.

\section{Materials and Methods}

Plant material. Cauliflower ( Brassica oleracea, Botrytis Group) florets, mature green tomato (Lycopersicon esculentum Mill.) fruit, and bell pepper fruit were examined in initial studies of low$\mathrm{O}_{2}$-imposed residual respiratory effects. For the reasons described in the Discussion section. this paper is limited to the results obtained with bell pepper.

Bell pepper fruit (var. 'Jupiter') were hand harvested at commercial maturity (green) and transported to the laboratory on the same day. Fruit were selected for uniform size and shape and freedom from defects. The fruit were wiped with paper towels moistened with $0.25 \%(\mathrm{v} / \mathrm{v})$ sodium hypochlorite (1:20 dilution of $5 \%$ commercial bleach). Individual fruit were placed into 1.7-liter glass jars and kept in a 20C room for $24 \mathrm{~h}$ to allow handlinginduced respiration to subside. Jars were sealed for $1 \mathrm{~h}$, and $0.5 \mathrm{ml}$ of headspace gas was removed for $\mathrm{CO}_{2}$ measurement. About $80 \%$ of the total fruit samples having $\mathrm{CO}_{2}$ production rates of $25 \pm 0.5$ $\mathrm{ml} \cdot \mathrm{kg}^{-1} \cdot \mathrm{h}^{-1}$ and an average weight of $160 \mathrm{~g}$ were selected for the experiments.

Gas treatments. Fruit were sealed individually in 1.7-liter glass jars and exposed to $1.5 \%, 5 \%$, or $10 \% \mathrm{O}_{2}$ in $\mathrm{N}_{2}$ for $24 \mathrm{~h}$ at $20 \mathrm{C}$. The control consisted of fruit exposed to air. Fruit also were stored in $1.5 \% \mathrm{O}_{2}$ for $72 \mathrm{~h}$ to determine the influence of prolonged exposure to low $\mathrm{O}_{2}$ on the extent of the residual effect. There were three fruit 
for each treatment, and each fruit constituted a replicate. The humidified $\mathrm{O}_{2}$ mixtures or air were introduced by means of a continuous flow-through system, and the flow rates were adjusted to keep $\mathrm{CO}_{2}$ levels $<0.3 \%$. After treatment in low $\mathrm{O}_{2}$ or air, all fruit were transferred to air and ventilated with humidified air at 20C. Gas measurements and ethanol content from the headspace gas were determined at various intervals during this subsequent storage in air.

In a separate experiment, bell pepper fruit were exposed to $4 \%$ $\mathrm{O}_{2}$ or air for 24 or 72 hat $20 \mathrm{C}$ and then transferred to air at the same temperature.

Gas measurements. The rates of $\mathrm{CO}_{2}$ and $\mathrm{C}_{2} \mathrm{H}_{4}$ production and $\mathrm{O}_{2}$ uptake were measured within $10 \mathrm{~min}$ after $24 \mathrm{~h}$ of exposure to the various $\mathrm{O}_{2}$ mixtures or air. Subsequent measurements were taken after $2 \mathrm{~h}$ and again at intervals following transfer of the fruit to air. For determining $\mathrm{CO}_{2}$ production and $\mathrm{O}_{2}$ uptake, $0.5 \mathrm{ml}$ of the headspace gas (1.7-liter jars sealed for $1 \mathrm{~h}$ ) was injected into a Fisher Model 1200 gas partitioner (Pittsburgh) equipped with a thermal conductivity detector, and Column Pak and molecular sieve columns at $60 \mathrm{C}$. Ethylene in $0.5-\mathrm{ml}$ samples of headspace gas was measured using a Photovac Model 10A 10 gas chromatograph (Thomhill, Ont., Canada) fitted with a photoionization detector and activated alumina column at ambient temperature.

Ethanol was determined using the Kentville Method (Lidster et al., 1985) following transfer to air by injecting $0.2 \mathrm{ml}$ headspace gas into a gas chromatograph equipped with a flame ionization detectorand 5\% carbowax (80/120mesh) column operated at $80 \mathrm{C}$. The detector and injector settings were at 100C. Peak heights were compared to a standard curve prepared from the headspace of a series of ethanol dilutions in double-distilled water kept at 20C. This method was able to detect ethanol concentrations as low as $0.01 \%$ in the headspace gas.

Mitochondria isolation. Pericarp tissue (100 $\mathrm{g}$ fresh weight), obtained from the equatorial region of pepper fruit, was diced $(\approx 2$ $\times 2 \mathrm{~mm}$ ) and the sections immersed in $150 \mathrm{ml}$ of ice-cold grinding buffer containing $0.4 \mathrm{~m}$ sucrose, $0.05 \mathrm{~m}$ Trizma base (Sigma Chemical Co.), 1 mm ethylene glycol-bis (B-aminoethyl ether $\mathrm{N}, \mathrm{N}, \mathrm{N}$ ', N'-tetraacetic acid (EGTA), $10 \mathrm{~mm} \mathrm{~K} \mathrm{H_{2 }} \mathrm{P} \mathrm{O}_{4}, 4$ mм cysteine, and $1 \%(\mathrm{w} / \mathrm{v})$ bovine serum albumin (BSA), adjusted to $\mathrm{pH}$ 7.6 with $\mathrm{HCl}$. The tissue was disrupted with a Polytron homogenizer (Brinkmann Instruments, Rexdale, Ont., Canada) for 2 to 3 sec at a speed setting of seven, followed by filtration through two layers of Miracloth (Calbiochem, La Jolla, Calif.). The filtrate was centrifuged at 1 to $4 \mathrm{C}$ for $10 \mathrm{~min}$ at $1000 \times \mathrm{g}$ to remove cell debris, followed by centrifugation of the supernatant for another $10 \mathrm{~min}$ at $1000 \times g$ to remove the remaining cell debris and other denser particles. Crude mitochondrial pellets were obtained by centrifugation of the supernatant at $16,000 \times \mathrm{g}$ for $10 \mathrm{~min}$. The pellets were resuspended in ice-cold medium containing $0.4 \mathrm{M}$ mannitol, $10 \mathrm{~mm}$ $\mathrm{KH}_{2} \mathrm{PO}_{4}$, and $0.5 \%$ (w/v) BSA adjusted to $\mathrm{pH} 7.2$ with $\mathrm{KOH}$, and the crude mitochondrial suspension was brought to a volume of 8 $\mathrm{ml}$.

Four milliliters of the mitochondrial suspension were layered onto a step gradient of Percoll (Sigma) following the methods of Moreau and Romani (1982), Duncan and Spencer (1987), and Phelps and McDonald (1990). with the following modifications: The gradient consisted of two steps of $20 \%$ and $45 \%$ Percoll with $0.25 \mathrm{M}$ mannitol, $10 \mathrm{~mm} \mathrm{~K} \mathrm{H}_{2} \mathrm{PO}_{4}$, and $0.5 \%$ (w/v) BSA, pH 7.2. Centrifugation of the gradients was at $26,000 \times g$ for $15 \mathrm{~min}$. The mitochondria banded at a density of $\approx 1.06$ as determined with density marker beads (Sigma), and were collected with a pasteur pipette. The mitochondria fraction was diluted to $20 \mathrm{ml}$ and washed with resuspension buffer without BSA and centrifuged at
$26,000 \times g$ for $20 \mathrm{~min}$. Final washing was in resuspension buffer without BSA at $16,000 \times g$ for $20 \mathrm{~min}$. The pellet was resuspended in a reaction medium containing $0.25 \mathrm{~m}$ sucrose, $10 \mathrm{~mm} \mathrm{~K} \mathrm{H}_{2} \mathrm{PO}_{4}$, $10 \mathrm{~mm}$ Tris $\mathrm{HCl}, 0.5 \mathrm{~mm}$ ethylenediaminetetraacetic acid (EDTA), $4 \mathrm{mM} \mathrm{MgCl}_{2}$, and $0.05 \%$ (w/v) BSA, pH 7.2. All steps involved in isolating Percoll gradient-purified mitochondria were conducted at 1 to $4 \mathrm{C}$.

Mitochondrial oxygen uptake. Oxygen consumption was measured at 20C with an oxygen electrode (Model 53, Yellow Springs Instruments Co., Yellow Springs, Ohio), standardized against airsaturated deionized water. Aliquots of $1.5 \mathrm{ml}$ of the mitochondrial suspension were placed into a sample chamber containing $2 \mathrm{~mm}$ succinate and $150 \mu \mathrm{M}$ adenosine 5'-diphosphate (ADP) to initiate state-3 respiration. The final volume of the solution in the reaction chamber was $3 \mathrm{ml}$. Oxygen consumption rate was expressed as nmol $\mathrm{O}_{2} / \mathrm{mg}$ mitochondrial protein per min, and was calculated from steady state $\mathrm{O}_{2}$ consumption values attained within $5 \mathrm{~min}$ after addition of succinate and ADP. Protein was determined following the method of Smith et al. (1985) using Pierce bicinchoninic acid (BCA) protein assay reagents (Sigma) and BSA as standard.

Enzyme assays. Cytochrome c oxidase (EC 1.9.3.1), a mitochondrial marker (Quail, 1979). was assayed by measuring the absorbance reduction of reduced cytochrome c at $550 \mathrm{~nm}$ (Storrie and Madden, 1990) using a Beckman spectrophotometer (Model DU-20, Irvine, Calif.). Catalase (EC 1.11.1.6). a peroxisome marker (Quail, 1979), was assayed by measuring the absorbance reduction of $\mathrm{H}_{2} \mathrm{O}_{2}$ at $240 \mathrm{~nm}$ (Luck, 1965).

Mitochondrial integrity. The intactness of purified mitochondria was evaluated according to Storrie and Madden (1990) by measuring the activity of cytochrome $\mathrm{c}$ oxidase in the presence or absence of nonionic detergent (Lubrol, Sigma).

\section{Results}

The magnitude of reduction in $\mathrm{CO}_{2}$ production after low $\mathrm{O}_{2}$ storage was greatest in fruit stored in $1.5 \% \mathrm{O}_{2}$ relative to $5 \%$ or $10 \%$ $\mathrm{O}_{2}$, and air (Fig. 1). The $\mathrm{CO}_{2}$ production rate of fruit measured after $24 \mathrm{~h}$ in $1.5 \% \mathrm{O}_{2}$ was $53 \%$ lower than that of the air-stored fruit when measured within $10 \mathrm{~min}$ of return to air. Preliminary experiments indicated that $\approx 2 \mathrm{~h}$ were required for the atmosphere inside the locules of fruit from the $1.5 \% \mathrm{O}_{2}$ treatment to equilibrate with an atmosphere of $21 \%$ (data not shown). Oxygen concentrations were measured in the fruit locule after $24 \mathrm{~h}$ in $1.5 \% \mathrm{O}_{2}$ and at $30 \mathrm{~min}$ intervals following transfer to air until an equilibrium was reached. The $\mathrm{CO}_{2}$ production rate of fruit stored in $1.5 \% \mathrm{O}_{2}$ continued to be suppressed, and attained values similar to the air-stored fruit only after $24 \mathrm{~h}$ in air (Fig. 1). Treatment with $5 \%$ or $10 \% \mathrm{O}_{2}$ had no consistent effect on the $\mathrm{CO}$, production rate upon transfer of bell pepper fruit to air. Within several hours in air, the $\mathrm{CO}_{2}$ production rates of fruit previously stored in $5 \%$ or $10 \% \mathrm{O}_{2}$ reached values similar to those of fruit stored continuously in air. Extending the storage period of bell pepper fruit in $1.5 \% \mathrm{O}_{2}$ from 24 to $72 \mathrm{~h}$ suppressed $\mathrm{CO}_{2}$ production for $48 \mathrm{~h}$ following transfer to air (Fig. 2). Ethanol was not detected in the headspace gas obtained from fruit after storage in $1.5 \% \mathrm{O}_{2}$ for 24 or $72 \mathrm{~h}$.

The $\mathrm{O}_{2}$ consumption rate of bell pepper fruit stored in $1.5 \%$ or $5 \% \mathrm{O}_{2}$ for $24 \mathrm{~h}$ was reduced by $\approx 80 \%$ or $40 \%$, respectively, compared to the air-stored fruit (Fig. 3). While there was about a $35 \%$ recovery in the $\mathrm{O}_{2}$ consumption rate $24 \mathrm{~h}$ after transfer from $1.5 \% \mathrm{O}_{2}$ to air, the $\mathrm{O}_{2}$ consumption rate recovered by $\approx 50 \%$ following storage in $5 \% \mathrm{O}_{2}$. The $\mathrm{O}_{2}$ consumption rates of fruit stored in $10 \% \mathrm{O}_{2}$ or after $24 \mathrm{~h}$ transfer to air were not significantly 


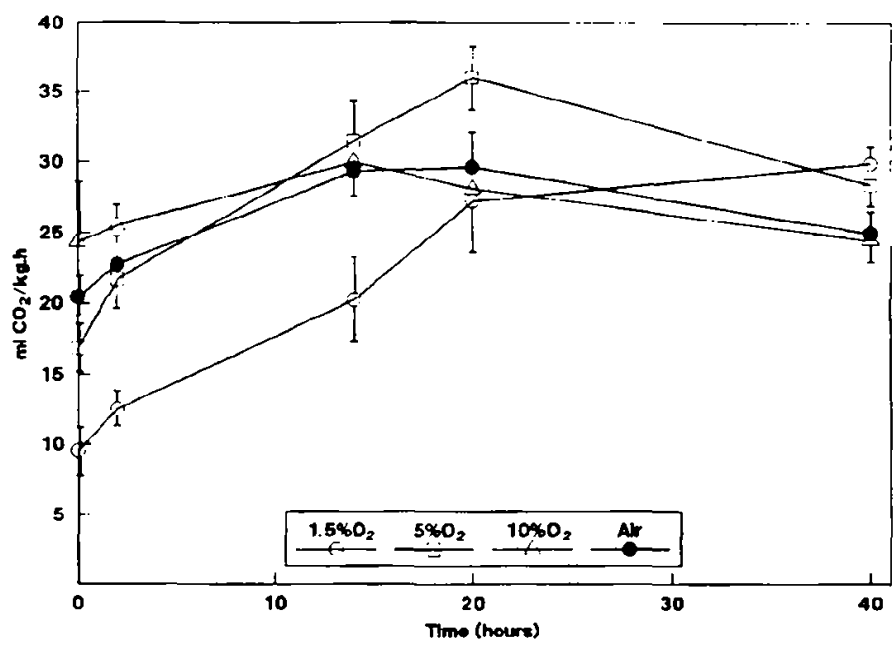

Fig. 1. Carbon dioxide production rates of bell pepper fruit in air following storage in $1.5 \%, 5 \%$, or $10 \% \mathrm{O}_{2}$, or in air for $24 \mathrm{~h}$ at $20 \mathrm{C}$. Vertical lines represent sD of the mean. Values are the means of three replications.

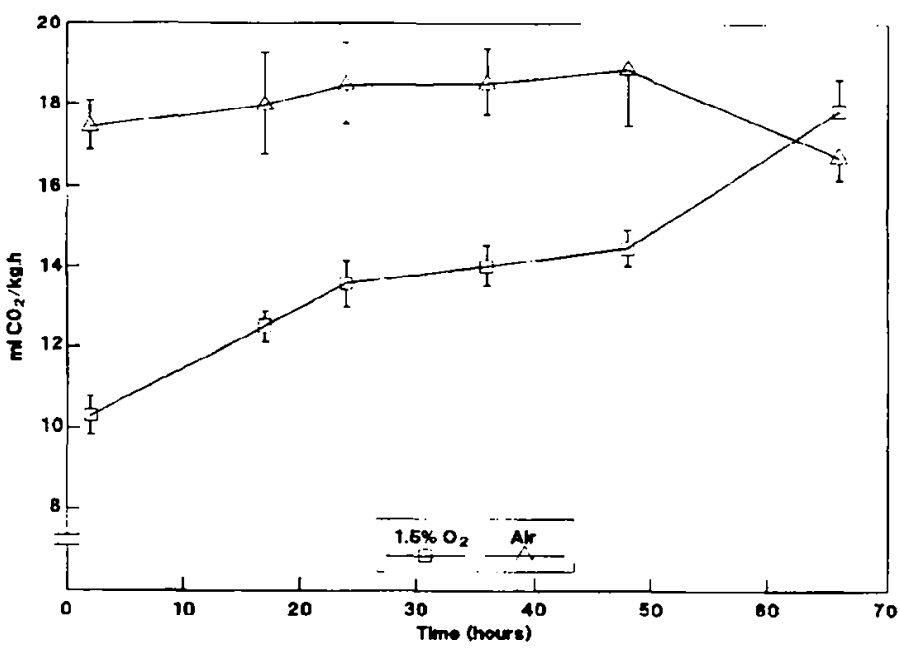

Fig. 2. Carbon dioxide production rates of bell pepper fruit in air after storage in $1.5 \% \mathrm{O}_{2}$, or in air for $72 \mathrm{~h}$ at $20 \mathrm{C}$. Vertical lines represent SD of the mean. Values are the means of threc replications.

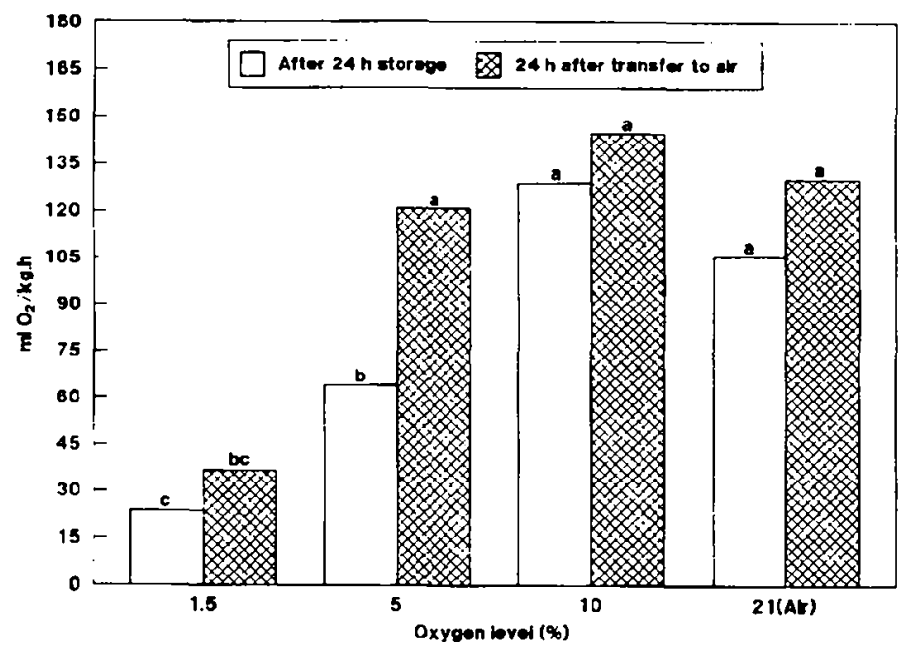

Fig. 3. Oxygen consumption rates of bell pepper fruit after storage in $1.5 \%, 5 \%$, or $10 \% \mathrm{O}_{2}$, or in air for $24 \mathrm{~h}$ at $20 \mathrm{C}$, and $24 \mathrm{~h}$ after transfer to air. Values are the means of three replications. Mean separation at $P=0.01$ by Duncan's Multiple Range Test. different $(P \leq 0.01)$ from those of fruit stored continuously in air.

Fruit stored for $24 \mathrm{~h}$ in $1.5 \% \mathrm{O}_{2}$ had a respiratory quotient (RQ) of $\approx 1.15$, which had decreased to $0.9524 \mathrm{~h}$ after transfer to air.

The $\mathrm{CO}_{2}$ production rate of bell pepper fruit that had been stored in $4 \% \mathrm{O}_{2}$ for $24 \mathrm{~h}$ was $\approx 25 \%$ lower than that of air-stored fruit measured within $10 \mathrm{~min}$ of transfer to air (Fig. 4A). The reduced $\mathrm{C} \mathrm{O}_{2}$ production was highly apparent during the first $6 \mathrm{~h}$ after transfer to air. After $\approx 24 \mathrm{~h}$ in air, the $\mathrm{CO}_{2}$ production rate was similar to that of the air-stored fruit. There was no difference in the $\mathrm{C}_{2} \mathrm{H}_{4}$ production rates between fruit stored in $4 \% \mathrm{O}_{2}$ and air (Fig. 4B).

Carbon dioxide production rates measured within 10 min after $72 \mathrm{~h}$ of storage in $4 \% \mathrm{O}_{2}$ were $38 \%$ lower than the air-stored sample (Fig. 5A). Later. the values generally were not significantly different from fruit stored continuously in air. The $\mathrm{C}_{2} \mathrm{H}_{4}$ production rates of fruit previously stored in $4 \% \mathrm{O}_{2}$ for $72 \mathrm{~h}$ and then transferred to air were similar to those stored continuously in air (Fig. 5B).

Mitochondria were isolated from the fruit to determine whether the low $\mathrm{O}_{2}$-induced residual respiratory effect could be explained by limitations in mitochondrial oxidative capacity. Purification of

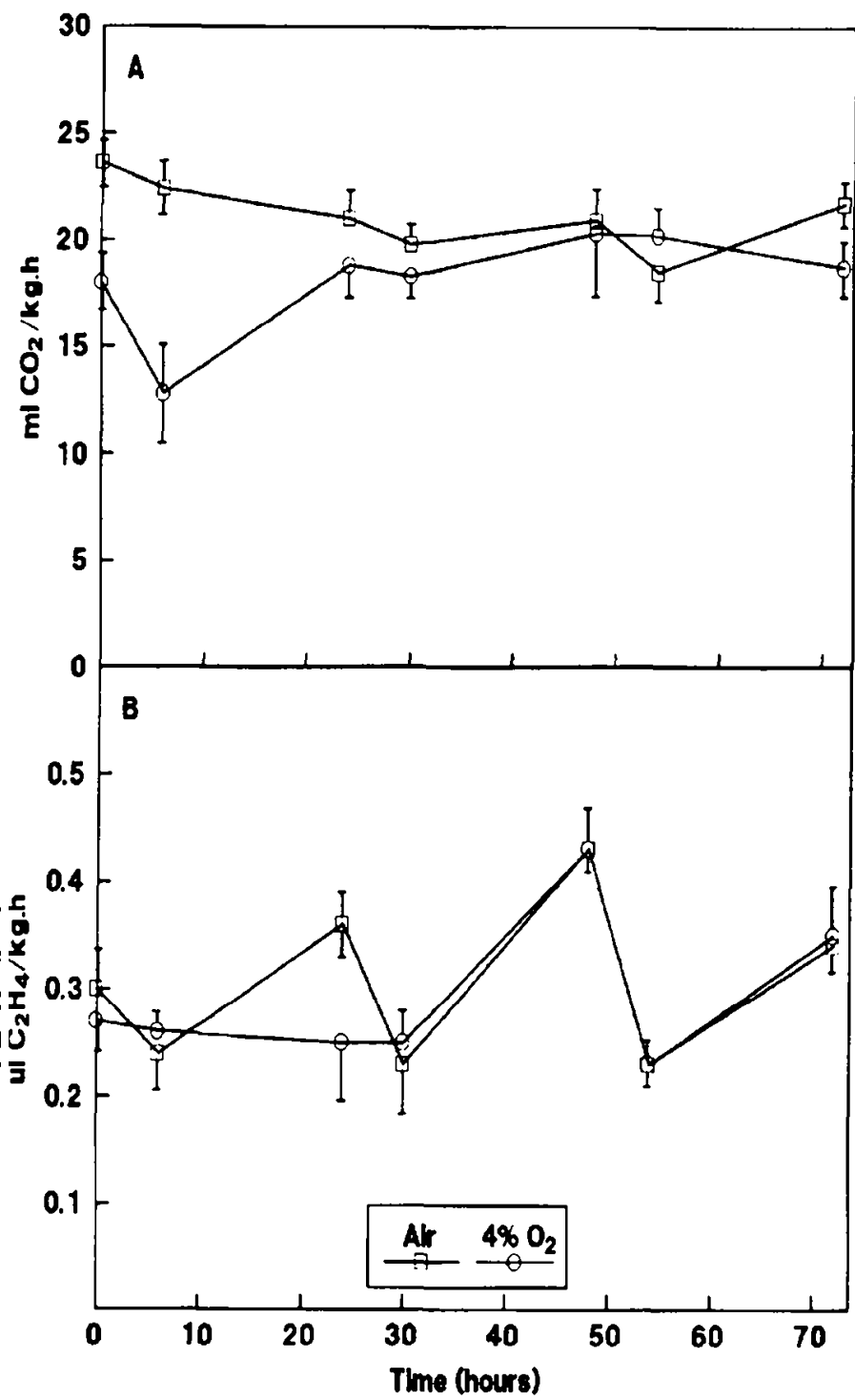

Fig 4. Carbon dioxide (A) and ethylene (B) production rates of bell pepper fruit in air after $24 \mathrm{~h}$ of storage in $4 \% \mathrm{O}_{2}$, and of continuously air-stored samples at $20 \mathrm{C}$. Vertical lines represent sD of the mean. Values are the means of three replications. 


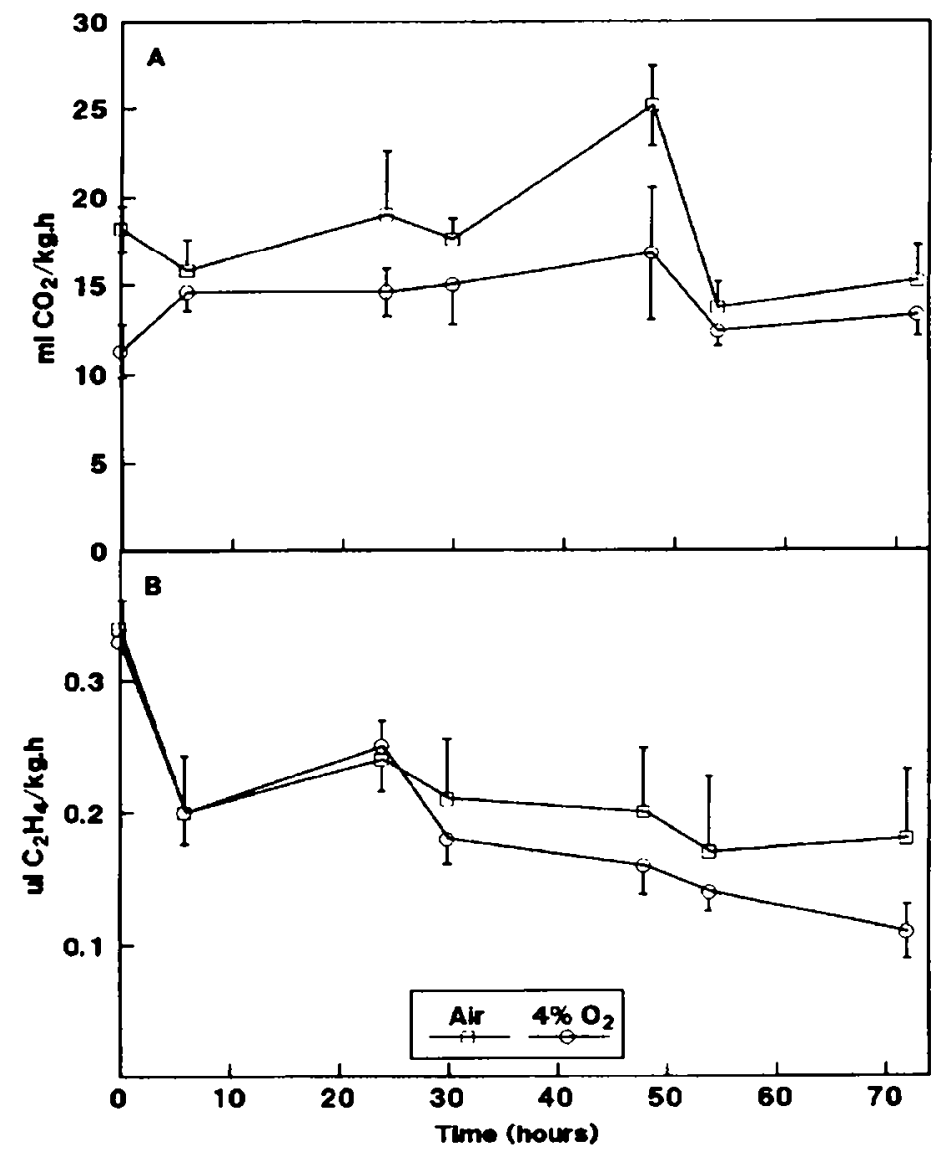

Fig. 5. Carbon dioxide (A) and ethylene (B) production rates of bell pepper fruit in air after $72 \mathrm{~h}$ of storage in $4 \% \mathrm{O}_{2}$, and of continuously air-stored samples at $20 \mathrm{C}$. Vertical lines represent SD of the mean. Values are the means of three replications.

crude mitochondrial extracts on Percoll gradients yielded mitochondria free from contaminating peroxisomes, microsomal membranes, and thylakoid fragments, with $\approx 90 \%$ intact. The steadystate oxidative capacity of mitochondria isolated from bell pepper fruit stored in $4 \% \mathrm{O}_{2}$ for 3 days showed no marked difference from the mitochondria of air-stored fruit (Fig. 6). Steady state $\mathrm{O}_{2}$ uptake rates were maintained for periods up to $20 \mathrm{~min}$, at which time dissolved $\mathrm{O}_{2}$ was nearly depleted. Mitochondria from fruit stored for 4 days in air or 3 days in $4 \% \mathrm{O}_{2}$ plus 1 day in air had higher rates of $\mathrm{O}_{2}$ uptake than mitochondria from fruit stored only 3 days. The $\mathrm{O}_{2}$ uptake capacity of mitochondrial isolates obtained from fruit stored in $1.5 \% \mathrm{O}_{2}$ for 1 day was also similar to those isolated from air-stored samples (Fig. 7).

\section{Discussion}

Several criteria were employed in selecting an appropriate commodity for the present study. The commodity 1) should exhibit a poststorage, residual respiratory response to low $\mathrm{O}_{2}$, with "respiration" defined as the organ's net exchange of $\mathrm{CO}_{2}$ or $\mathrm{O}_{2}$ without regard to the cellular sites of production or consumption; 2) should not exhibit rapid developmental changes during the experimental period; and 3) should allow the isolation of relatively pure, highintegrity mitochondria. Among three commodities initially examined (bell pepper fruit, tomato fruit, and cauliflower florets), bell pepper best satisfied the above criteria. Comparisons of the residual effects of low $\mathrm{O}_{2}$ imposed on tomato fruit respiration were confounded by the differential influence of low $\mathrm{O}_{2}$ and air on the

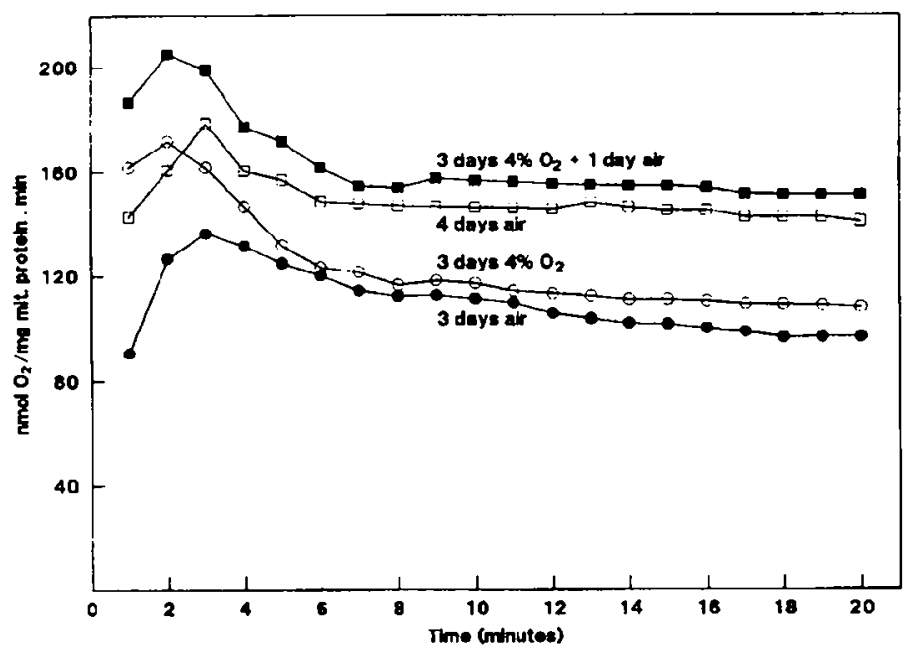

Fig. 6. Oxygen uptake capacity of isolated mitochondria from bell pepper fruit stored for 3 days in $4 \% \mathrm{O}_{2}, 3$ days in air, 4 days in air, or 3 days in $4 \% \mathrm{O}_{2}$ plus 1 day in air. Values are the means of two replications.

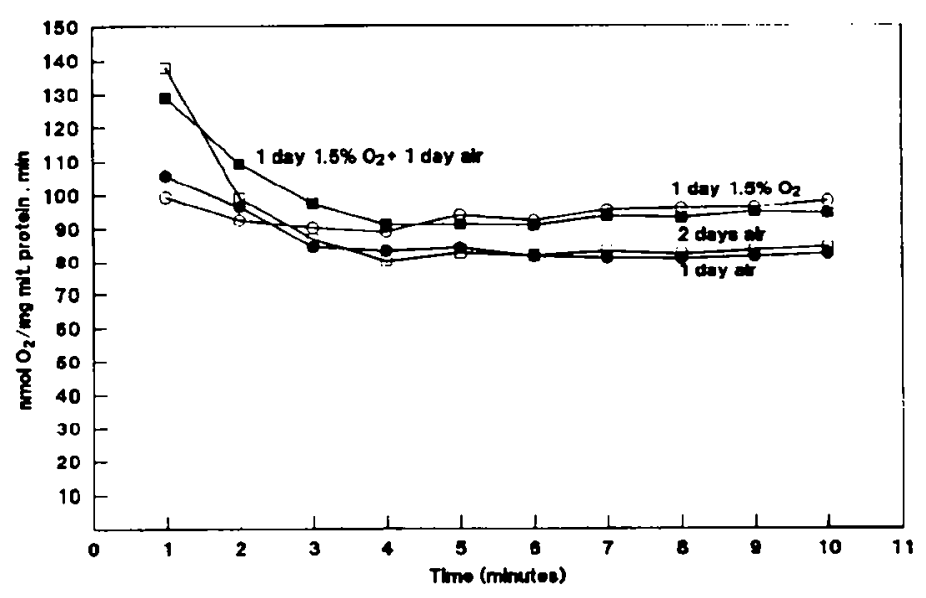

Fig. 7. Oxygen uptake capacity of isolated mitochondria from bell pepper fruit stored for 1 day in $1.5 \% \mathrm{O}_{2}, 1$ day in air, 2 days in air, or 1 day in $1.5 \% \mathrm{O}_{2}$ plus 1 day in air. Values are the means of two replications.

onset of ripening and the associated respiratory climacteric. Cauliflower florets. however, exhibited no apparent residual response of net gas exchange to low- $\mathrm{O}_{2}$ storage.

The rationale for investigating the poststorage residual effect of low $\mathrm{O}_{2}$ on respiratory activity is 2-fold. First, practical postharvest benefits may be derived from such a "plastic" response to low $\mathrm{O}_{2}$. For example, Li and Kader (1989) indicated that exposing strawberries to an atmosphere containing $1 \%$ to $2 \% \mathrm{O}_{2}$ for at least 3 days at $2 \mathrm{C}$ could maintain quality during transport or temporary storage, and that such a low- $\mathrm{O}_{2}$ exposure reduced deterioration during subsequent handling in air. Second, the maintenance of presumed low $\mathrm{O}_{2}$-imposed metabolism upon transfer to air presents the opportunity for experimental elucidation, under ambient conditions, of the effects of low- $\mathrm{O}_{2}$ storage.

These studies demonstrate that the respiration of bell pepper fruit is affected by prior storage under reduced $\mathrm{O}_{2}$ levels. Kader ( 1992) indicated that the recommended level of $\mathrm{O}_{2}$ for CA or MA storage of bell pepper is between $3 \%$ and $5 \%$. The results of the present study demonstrate that $1.5 \% \quad \mathrm{O}_{2}$ is more effective in reducing the respiration rate of bell pepper fruit than are higher $\mathrm{O}_{2}$ levels. Additionally, the continued suppression of $\mathrm{CO}_{2}$ production or $\mathrm{O}_{2}$ consumption after return of the pepper fruit to air indicates 
the presence of a residual effect as a consequence of prior exposure to low $\mathrm{O}_{2}$. The residual effect exhibited by bell pepper fruit stored in $1.5 \% \mathrm{O}_{2}$ was apparent for almost $24 \mathrm{~h}$ after transfer to air. Thereafter, the pepper fruit recovered and attained respiration rates similar to those of continuously air-stored fruit. A residual effect of low $\mathrm{O}_{2}$ on respiration and $\mathrm{C}_{2} \mathrm{H}_{4}$ production rates has been demonstrated in 'Selva' strawberries by $\mathrm{Li}$ and Kader (1989). They indicated that low $\mathrm{O}_{2}(0.5 \%$ to $2 \%)$ reduced respiration and ethylene production rates during $\mathrm{CA}$ storage and after subsequent holding in air for 7 days at 2C. Ke and Kader (1990) reported that 'Valencia' oranges ( Citrus sinensis Osb.) tolerated up to 20 days of exposure to $0.5 \%, 0.25 \%$, or $0.02 \% \mathrm{O}_{2}$ at $\mathrm{SC}$ or $10 \mathrm{C}$, followed by holding in air at $5 \mathrm{C}$ for 7 days without any detrimental effects on external or internal appearance.

Storage of fresh fruits and vegetables under excessively low levels of $\mathrm{O}_{2}$ may induce the accumulation of ethanol, which results in off-flavors (Ke et al., 1990). The absence of detectable levels $(<0.01 \%)$ of ethanol in the headspace gas from bell pepper fruit stored in $1.5 \% \mathrm{O}_{2}$ indicates that the residual influence on respiration rate was not due to anaerobiosis induced by low- $\mathrm{O}_{2}$ storage. While ethanol evaporates into the headspace gas, a considerable fraction may be retained in the fruit tissues. 'Bartlett' pears ( Pyrus communis L.) stored in $0.5 \%$ or $1.0 \% \mathrm{O}_{2}$ for 10 days at 0,5 , or $10 \mathrm{C}$ had almost the same levels of ethanol as the pears stored continuously in air, while $0.25 \% \mathrm{O}_{2}$ caused a slight increase (Ke et al., 1990).

The reduction in $\mathrm{CO}_{2}$ production of bell pepper transferred from low $\mathrm{O}_{2}$ to air persisted for $\approx 24 \mathrm{~h}$, but was not significantly different after $72 \mathrm{~h}$ in $4 \% \mathrm{O}_{2}$. In contrast, storage of fruit in $1.5 \% \mathrm{O}_{2}$ for 72 $\mathrm{h}$ suppressed $\mathrm{CO}_{2}$ production for $\approx 48 \mathrm{~h}$. The residual effect likely is prolonged as the storage period under $1.5 \% \quad \mathrm{O}_{2}$ is extended.

The RQ values of about one exhibited by fruit stored in $1.5 \% \mathrm{O}_{2}$ for $24 \mathrm{~h}$ or after transfer to air indicates that anaerobiosis is not occurring in the fruit tissues. According to Hole et al. (1992), the RQ under aerobic conditions is about one when glucose or other hexose sugars are used as the predominant $\mathrm{C}$ source in glycolysis. When a hypoxic condition was induced in highbush blueberry (Vaccinium corymbosum L.) fruit sealed in low-density polyethylene packages at $25 \mathrm{C}$, an $\mathrm{RQ}$ of $\approx 3$ was measured (Beaudry et al., 1992).

In nonclimacteric bell pepper fruit, the $\mathrm{C}_{2} \mathrm{H}_{4}$ production rates were not affected by prior exposure to $1.5 \%$ (data not shown) or $4 \%$ $\mathrm{O}_{2}$ (Saltveit, 1977). Therefore, there is no residual effect of low $\mathrm{O}_{2}$ on the $\mathrm{C}_{2} \mathrm{H}_{4}$ production rate of bell peppers. In contrast, low $\mathrm{O}_{2}$ often delays the onset of the rise in $\mathrm{C}_{2} \mathrm{H}_{4}$ and other changes associated with ripening in climacteric fruits (Hesselman and Freebaim, 1969).

The $\mathrm{O}_{2}$ consumption rate was affected to a greater extent than the $\mathrm{CO}_{2}$ production rate in fruit exposed to low $\mathrm{O}_{2}$. An $\mathrm{O}_{2}$ level of $1.5 \%$ exerted a greater residual effect than intermediate levels. The continued suppression of $\mathrm{O}_{2}$ consumption rate upon transfer to air clearly demonstrates the pronounced residual effect from prior exposure to this low oxygen level. Earlier studies indicated that gas diffusion through fruit tissues is quite rapid. Hence, it is unlikely that the residual effect following storage of fruit in $1.5 \% \mathrm{O}_{2}$ results from resistance to gas diffusion through the fruit tissues.

The biochemical basis of the residual gas-exchange response is not known. In terms of cellular $\mathrm{O}_{2}$ consumption, relevant enzymes have been categorized as low-affinity (high $\mathrm{Km}$ ) or high-affinity (low $\mathrm{Km}$ ) oxidases. Low-affinity oxidases include polyphenol oxidase, lipoxygenase, and ascorbic acid oxidase, whereas the primary high-affinity oxidase is cytochrome oxidase (Malmstrom,
1990). Studies by Burton (1982) on potato ( Solanum tuberosum L.) tubers indicated that $1 \%$ gas phase $\mathrm{O}_{2}$ would result in steadystate, cellular sap $\mathrm{O}_{2}$ levels of $1.2 \times 10^{-5} \mathrm{M}$. Under this condition, $\mathrm{O}_{2}$ consumption by cytochrome oxidase was inhibited $<1 \%$ relative to values observed in air. In agreement with these considerations, our studies revealed no residual influence of low $\mathrm{O}_{2}(1.5 \%$ or $4.0 \%)$ on the oxidative capacity of mitochondria isolated from bell pepper fruit. While the residual respiratory response of intact bell pepper possibly is due, in part, to indirect effects on cytochrome oxidase (e.g., reduced carbon flux), our data reveal no residual impairment in the capacity of isolated mitochondria to oxidize exogenously added substrates.

We speculate that the residual respiratory responses may be explained as the suppression of extramitochondrial, low-affinity oxidases. Under gas phase $\mathrm{O}_{2}$ of $1 \%$, dissolved $\mathrm{O}_{2}$ levels would result in a nearly 95\% inhibition of these enzymes (Burton, 1982). Studies by Mapson and Burton (1962). indicated that $\approx 70 \%$ of the respiration of potato tuber in air occurred through cytochrome oxidase, and $30 \%$ through the low-affinity oxidases. The proportion of respiration passing through the low-affinity oxidases in $100 \% \mathrm{O}_{2}$ was increased to $\approx 50 \%$.

In summary, reducing the $\mathrm{O}_{2}$ concentration to $1.5 \%$ and prolonging the exposure period to $72 \mathrm{~h}$ resulted in a longer poststorage residual effect on the $\mathrm{CO}_{2}$ production and $\mathrm{O}_{2}$ consumption. Ethylene production rate was not affected by storage in $1.5 \%$ or $4 \% \mathrm{O}_{2}$ for 24 or $72 \mathrm{~h}$. The absence of ethanol indicates that the residual effect induced by $1.5 \% \quad \mathrm{O}_{2}$ is not injurious to the fruit tissue. Additionally, the residual effect of low $\mathrm{O}_{2}$ on the respiratory activity of intact fruit is not apparent in isolated mitochondria.

\section{Literature Cited}

Aharoni, Y., P. Hartsell, J.K. Stewart, and D.K. Young. 1979. Control of western flower thrips on harvested strawberries with acetaldehyde in air, $50 \% \mathrm{CO}_{2}$ or $1 \% \mathrm{O}_{2}$. J. Econ. Entomol. 72:819.

Beaudry, R.M., A.C. Cameron, A. Shirazi, and D.L. Dostal-Lange. 1992. Modified-atmosphere packaging of blueberry fruit: Effect of temperature on package $\mathrm{O}_{2}$ and $\mathrm{CO}_{2}$. J. Amer. Soc. Hort. Sci. 117:436-441.

Burton, W.G. 1978. Biochemical and physiological effects of modified atmospheres and their role in quality maintenance, p. 97. In: H.O. Hultin and M. Milner (eds.). Postharvest biology and biotechnology. Food and Nutrition Press, Westport, Conn.

Burton, W.G. 1982. Post-harvest physiology of food crops. Longman, New York.

Davis, P.L., B. Roe, and J.H. Bruemmer. 1973. Biochemical changes in citrus fruits during controlled atmosphere storage. J. Food Sci. 38:225229.

Duncan, I. and M. Spencer. 1987. Changes in respiration of mitochondria isolated from cotyledons of ethylene-treated pea seedlings. Planta 170:44-48

Hesselman, C.W. and H.T. Freebaim. 1969. Rate of ripening of initiated bananas as influenced by oxygen and ethylene. J. Amer. Soc. Hort. Sci. 94:635-637.

Hole, D.J., B.C. Cobb, P.S. Hole, and M.C. Drew. 1992. Enhancement of anaerobic respiration in root tips of Zea mays following low-oxygen (hypoxic) acclimation. Plant Physiol. 99:213-218.

Kader, A.A. 1986. Biochemical and biophysical basis for effects of controlled and modified atmospheres on fruits and vegetables. Food Technol. 40:99-104.

Kader, A.A. 1992. Modified atmospheres during transport and storage, p. 88. In: A.A. Kader (ed.). Postharvest technology of horticultural crops, 2nd ed. Div. of Agr. and Natural Resources, Univ. of California, Davis. Ke, D. and A.A. Kader. 1990. Tolerance of 'Valencia' oranges to controlled atmosphere as determined by physiological responses and quality attributes. J. Amer. Soc. Hort. Sci. 115:779-783.

Ke, D., L. Rodriguez-Sinobas, and A.A. Kader. 1991. Physiology and 
prediction of fruit tolerance to low oxygen atmospheres. J. Amer. Soc. Hort. Sci. 116:253-260.

Ke, D., H. van Gorsel, and A.A. Kader. 1990. Physiological and quality responses of 'Bartlett' pears to reduced $\mathrm{O}_{2}$ and enhanced $\mathrm{CO}$, levels and storage temperature. J. Amer. Soc. Hort. Sci. 115:435-439.

Li, C. and A.A. Kader. 1989. Residual effects of controlled atmospheres on postharvest physiology and quality of strawberries. J. Amer. Soc. Hort. Sci. 114:629-634.

Luck, H. 1965. Catalase, p. 885-894. In: H.U. Bergmeyer (cd.). Methods of enzymatic analysis. Academic, New York.

Malmstrom, B.G. 1990. Cytochrome oxidase: Some unsolved problems and controversial issues. Arch. Biochem. Biophys. 280(2):233-241.

Mapson, L.W. and W.G. Burton. 1962. The terminal oxidases of the potato tuber. Biochem. J. 82:19-25.

Moreau, F. and R. Romani. 1982. Preparation of avocado mitochondria using self-generated percoll gradients and changes in buoyant density during ripening. Plant Physiol. 70:1380-1384.

Patterson, M.E. and W.C. Nichols. 1988. Metabolic responses of 'Delicious' apple to carbon dioxide in anoxic and low-oxygen environments.
HortScience 23:866-868.

Phelps, DC. and R.E. McDonald. 1990. Inhibition of electron transport activities in mitochondria from avocado and pepper fruit by naturally occurring polyamines. Physiol. Plant. 78:15-21.

Quail, P.H. 1979. Plant cell fractionation. Annu. Rev. Plant Physiol. 30:425-471.

Saltveit, M.E. 1977. Carbon dioxide, ethylene, and color development in ripening mature green bell peppers. J. Amer. Soc. Hort. Sci. 102:523-525. Smith, P.K., R.I. Krohn, G.T. Hermanson, A.K. Mallia, F.H. Gartner, M.D. Provenzano, E.K. Fujimoto, N.M. Geoke, B.J. Olson, and D.C. Klenk. 1985. Measurements of protein using bicinchoninic acid. Anal. Biochem. 150:76-85.

Solomos, T. 1982. Effect of low oxygen concentration on fruit respiration: Nature of respiratory diminution, p. 161. In: D.G. Richardson and M. Meheriuk (eds.). Controlled atmosphere for storage and transport of perishable agricultural commodities. Timber Press, Beaver\&on, Ore.

Storrie, B. and E.A. Madden. 1990. Isolation of subcellular organelles, 182:214-215. In: M.P. Deutsher (ed.). Guide to protein purification. Academic, San Diego. 